\title{
Management of Wisconsin Dairy Herds Enrolled in Milk Quality Teams
}

\author{
A. C. O. Rodrigues, D. Z. Caraviello, and P. L. Ruegg \\ Department of Dairy Science, University of Wisconsin, Madison 53706
}

\begin{abstract}
A study was conducted to characterize Wisconsin dairy herds that enrolled in a team-based milk quality improvement program and to assess association of specific management practices with milking efficiency and milk quality. Management and financial data were obtained from dairy farms $(n=180)$ that participated in the program. Upon enrollment, herds reported a median bulk milk somatic cell count (SCC) of 333,500 cells/ $\mathrm{mL}$, an average of 125 lactating cows, and a mean rolling-herd average of 10,100 kg. Many management practices and bulk milk SCC were strongly associated with herd size and facility type. Managers of herds housed in freestall barns adopted more standardized procedures and recommended management practices compared with managers of herds housed in stall barns. Those managers also reported less bulk milk SCC and greater milk yields, and had a tendency for lower prevalence of subclinical mastitis and reduced estimates of the incidence of clinical mastitis. Managers of freestall herds received more quality premiums for milk shipped, estimated that they had fewer financial losses related to mastitis, and reported more efficient milking performance. A more efficient milking performance did not increase estimates of clinical mastitis or bulk milk SCC. In herds having freestalls, frequent training of employees seemed to be the fundamental factor that increased milking efficiency. Bulk milk SCC was positively associated with standard plate count, estimated rate of clinical mastitis, prevalence of subclinical mastitis, numbers of cows culled for mastitis, and estimated financial losses attributable to mastitis. Herds reporting high bulk milk SCC had an increased prevalence of subclinical mastitis, but incidence did not differ among bulk milk SCC categories. Overall, herds did not discuss milk quality frequently with dairy professionals, and herds having greater bulk milk SCC reported less consultation with their herd veterinarian.
\end{abstract}

(Key words: management, mastitis, milk quality)

Received December 16, 2004.

Accepted March 21, 2005.

Corresponding author: P. L. Ruegg; e-mail: plruegg@wisc.edu.
Abbreviation key: BMSCC = bulk milk somatic cell count.

\section{INTRODUCTION}

Mastitis is a well-known multifactorial disease that is controlled using a variety of management and intervention practices. Mastitis is predisposed by an interaction among the causative agent (bacteria), the host (cow), and the environment. The farm environment influences exposure to microorganisms and the cow's ability to resist infection (Harmon, 1994). Environmental aspects include both seasonal effects and farm management practices. Use of appropriate management practices can reduce exposure to bacteria and enhance resistance to mastitis. An association between herd management practices and udder health status was previously demonstrated (Fenlon et al., 1995; Wilson et al., 1997; Barkema et al., 1998a). Use of practices that control contagious mastitis and regular milking machine maintenance are both commonly associated with lower bulk milk somatic cell count (BMSCC).

An understanding of farm management is only one aspect of mastitis control. Implementation of recommended management practices often depends on the ability of the farmer to motivate farm employees. There is some indication that larger farms produce better quality milk. An analysis of milk quality data from New York indicated that farms with monthly milk shipments $>68,000 \mathrm{~kg}$ had fewer lower BMSCC than herds that shipped less milk (van Schaik et al., 2002).

Failure to control mastitis results in significant financial losses for dairy farms. Financial losses attributable to clinical and subclinical mastitis include reduced milk production, treatment costs, discarded milk, and loss of quality milk bonuses. The inverse relationship between milk production and the prevalence of subclinical mastitis (as measured by SCC) is well documented (Harmon, 1994). Of the estimated $\$ 140$ to $\$ 300$ losses per cow per year attributed to mastitis, it is generally agreed that 70 to $80 \%$ is associated with reduced milk production caused by subclinical mastitis (Fetrow et al., 2000).

Purchase of poor quality milk also results in significant losses for processors. Milk that contains high numbers of somatic cells is associated with reduced cheese 
yields and shorter shelf life of finished products (Barbano, 2004). Injury to secretory alveoli reduces the synthesis of lactose, casein, fat, and concentration of whey proteins; and chloride and sodium increase due to leakage from blood. Increased proteolytic and lipolytic activities are associated with mastitis (Schallibaum, 2001). To encourage production of high quality milk, many dairy processors pay premiums for milk that contains low numbers of somatic cells.

Dairy professionals have developed many innovative programs for improving milk quality. In Wisconsin, dairy farms have the opportunity to join a statewide team-based milk quality program called "Milk Money." Milk Money was designed to help producers and dairy professionals promote improvement in milk quality and farm profitability. Enrollment in Milk Money began in November 2001 and is continuing. Upon enrollment, farms commit to form a milk-quality team of their choice and meet for 4 meetings (usually at monthly intervals), focusing on reaching self-defined milk quality goals. The objective of the present study was to: 1 ) characterize Wisconsin dairy herds that enrolled in a team-based program to improve milk quality, and 2) assess the association of specific management practices with milking efficiency and milk quality.

\section{MATERIALS AND METHODS}

\section{Data}

Data from Wisconsin dairy farms $(\mathrm{n}=180)$ participating in a statewide team-based milk quality program were collected by team leaders. Team leaders included extension professionals ( $\mathrm{n}=117$ teams), veterinarians ( $\mathrm{n}=39$ teams), other agri-professionals $(\mathrm{n}=17$ teams), and some farm owners ( $\mathrm{n}=7$ teams). The milk quality program consisted of 4 monthly meetings of a self-selected milk quality management team. Program materials included a guided situation assessment, a monthly action plan, and a comprehensive resource section. Teams were initiated in response to statewide recruitment efforts by extension professionals, private veterinarians, field staff of milk processors, or through selfreferral by the farm.

Data from farms that enrolled in the program beginning in fall 2001 and continuing through spring of 2004 were included in this analysis (Figure 1). Enrollment was continuous and voluntary. Data used in our analysis were collected only during the first milk-quality team meeting by the team leader. Dairy professionals that worked with the farms received training about the milk-quality program to standardize data collection and ensure use of uniform definitions. Data were sent to the university in preaddressed envelopes, entered in a database, and checked for reliability. Unreliable nu-

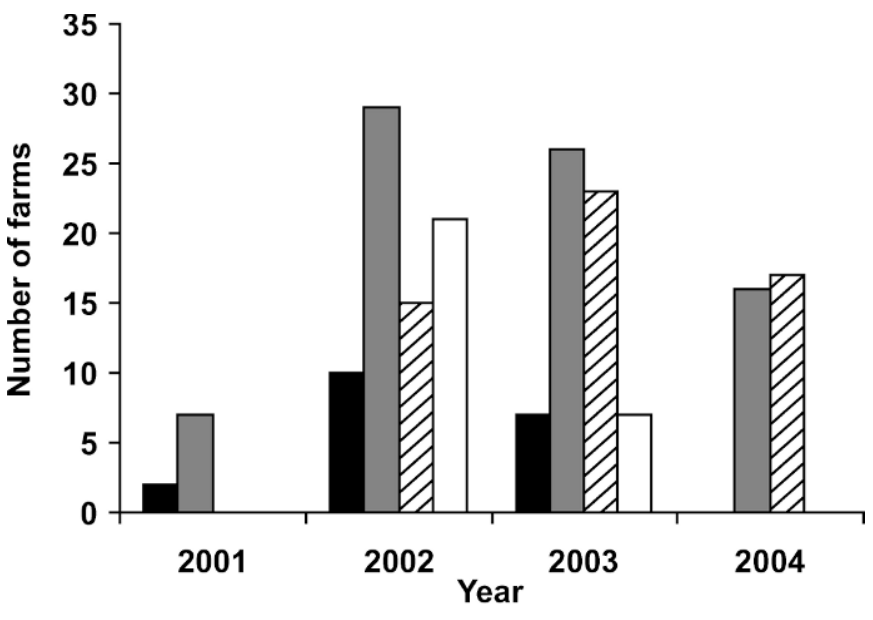

$\square$ Fall $\square$ Winter $\square$ Spring $\square$ Summer

Figure 1. Distribution of enrollment of farms included in the analysis by season and year.

merical values (such as excessive DIM, unrealistic days of milk discard per clinical mastitis case, or apparently erroneous calculations) were corrected after consultation with the team leader. Values that could not be recovered were omitted from the database. Less than $1 \%$ of the values required correction or omission. When program forms were missing, team leaders were contacted to supply the data. Unless otherwise indicated, data collected at the first meeting referred to the preceding month.

Results of a questionnaire administered at the first team meeting consisted of 29 questions regarding herd management practices. Data sources included milk plant receipts, farm records, DHI data from the current test date ( $\mathrm{n}=142$ herds), and farmer recall. Financial impact of milk quality was estimated using a worksheet that segregated losses into "production losses due to subclinical mastitis", "opportunity from milk quality premiums", and "estimated cost of clinical mastitis" (available at http://www.uwex.edu/milkquality/programs/forms/index.htm).

\section{Bulk Milk Culture}

Upon enrollment, farms received a package containing supplies and instructions for collection of bulk milk. Submission of bulk milk samples was voluntary and was not necessary for program enrollment. Usable samples of bulk milk were obtained from 92 herds. Each bulk milk sample was composed of 3 to 5 milk samples (approximately $50 \mathrm{~mL}$ each) obtained on consecutive days. Milk samples were frozen on the farms, and sent together to the university. After thawing and mixing, 
the samples were combined by aseptically transferring $5 \mathrm{~mL}$ from each sample. Composite milk samples having $\mathrm{pH}$ readings $<6.4$ were discarded.

Bacteriological examination of the bulk milk was done following guidelines described by Farnsworth (1993). In brief, 5\% sheep blood agar and MacConkey agar plates were inoculated with 3 dilutions (1:5, 1:50, and 1:500) in sterile water of the composite sample, and a Mycoplasma plate was inoculated with 1 dilution (1:5). After incubation, blood agar plates containing 10 to 300 colonies were chosen for enumeration of bacteria. Colony identification and differentiation were performed according to procedures of the National Mastitis Council (1999). After bacterial identification and enumeration, results were reported by bacterial species (Staphylococcus aureus and Streptococcus agalactiae) and bacterial group (coagulase-negative staphylococci, other streptococci, coliforms, and others).

\section{Definition of Variables}

The definition of clinical mastitis was farm-specific, was not standardized for this study, and represents the perception of clinical mastitis on each farm rather than the absolute rate. Estimated monthly rate of clinical mastitis was calculated as the total number of clinical mastitis cases reported during the preceding month divided by the average monthly number of lactating cows. Duration of milk discarded for clinical mastitis was estimated as the total number of days that the milk from a clinical mastitis case was withheld from the bulk tank. Financial losses for clinical mastitis were standardized by assessing constant drug cost of $\$ 15.00$, milk price of $\$ 0.24 / \mathrm{kg}$, and veterinary/labor cost of $\$ 50.00$ per case.

Information about milk premiums was obtained from milk checks or from a premium schedule provided by the individual processor. The BMSCC premium was the amount of money paid or deducted for $45 \mathrm{~kg}$ of milk based on the monthly average BMSCC. As part of the milk quality program, most farms also reported the premium that they would obtain if they had achieved their BMSCC goal.

\section{Statistical Analyses}

Statistical significance was declared at $P \leq 0.05$. Before statistical analyses, data were screened for errors. Descriptive statistics were calculated using PROC MEANS and PROC FREQ (SAS Institute, 2001). Herds were characterized by facility type [freestalls or stallbarns (tie stalls and stanchion facilities)] and BMSCC category [Low $(<250,000$ cell $\mathrm{s} / \mathrm{mL})$; Medium $(250,000$ to 400,000 cells $/ \mathrm{mL}$ ); and High (> 400,000 cells $/ \mathrm{mL})]$.
Relationships between variables and categories were investigated using PROC GLM (SAS Institute, 2001) for continuous variables and Pearson $\chi^{2}$ test (SAS Institute, 2001) for categorical variables.

Influence of the number of milkings per day on base 10 logarithm BMSCC, prevalence of subclinical mastitis, and rate of clinical mastitis was assessed for each facility type using PROC GLM (SAS Institute, 2001) in a model containing year and season.

Influence of the sequence of predipping and forestripping during premilking cow preparation on selected outcome variables was assessed for each facility type using PROC GLM in a model that included year and season.

Influence of selected milking practices on selected measures of milking performance was assessed for each facility type using PROC GLM in a model that included year and season. Separate models were developed for each facility type category.

Bacterial counts of bulk milk cultures were described as 25th, 50th, and 75th percentiles. Differences between the base 10 logarithms of bacterial counts were tested among facility types and BMSCC categories using PROC GLM. The influence of the use of predipping teat disinfection on bulk milk culture results was assessed using PROC GLM. The base 10 logarithms of bacterial counts were regressed in a model containing year and season.

The relationship between BMSCC and explanatory variables was tested using PROC MIXED (SAS Institute, 2001). The response variable, BMSCC, was transformed in the base 10 logarithm to normalize the response and was regressed on year, season, number of lactating cows, milk production per cow per day, and a explanatory variable of interest. Each herd characteristic (management and financial) and bacterial count was used individually as an explanatory variable in the regression model. Linear effects, nonlinear effects, and interactions were estimated for the explanatory variables. The equation for all models was:

$$
\begin{gathered}
\log _{10} \text { BMSCC }_{i j l m n}=\alpha+\text { year }_{i}+\text { season }_{j}+\text { herdsize }_{1} \\
+ \text { milkcowday }_{m}+\mathbf{x}_{\mathrm{n}}+\varepsilon_{\mathrm{ijlmn}}
\end{gathered}
$$

where $\log _{10} \mathrm{BMSCC}_{\mathrm{ijlmn}}=$ base 10 logarithm of monthly average BMSCC; $\alpha=$ intercept; year $_{\mathrm{i}}=$ year of milk quality program implementation (2001 to 2004); season $_{\mathrm{j}}=$ season of milk quality program implementation (fall, winter, spring, and summer); herdsize ${ }_{1}=$ monthly average number of lactating cows; milkcowday $_{\mathrm{m}}=$ monthly average milk production per cow per day; $\mathrm{x}_{\mathrm{n}}=$ explanatory variable of interest; and $\varepsilon_{\mathrm{ijl}} \mathrm{mn}=$ residual error. 
Table 1. Distribution of mean herd size among bulk milk SCC (BMSCC) categories. Number of herds in each category is shown in parentheses.

\begin{tabular}{lcccc}
\hline \multirow{2}{*}{$\begin{array}{l}\text { Facility } \\
\text { type }\end{array}$} & \multicolumn{3}{c}{ Mean herd size in each BMSCC category ${ }^{1}$} & \\
\cline { 2 - 4 } & Low & Medium & High & $P$ \\
\hline Freestall & $329(19)$ & $421(59)$ & $306(23)$ & 0.301 \\
Stallbarn & $86(17)$ & $94(23)$ & $82(37)$ & 0.807 \\
$P$ & 0.005 & $<0.001$ & $<0.001$ & \\
\hline
\end{tabular}

${ }^{1}$ Bulk tank SCC: Low $=<250,000$ cell $/ \mathrm{mL} ;$ Medium $=250,000$ to 400,000 cells $/ \mathrm{mL}$; and High $=>400,000$ cells $/ \mathrm{mL}$.

\section{RESULTS}

\section{Herd Characteristics and Management Practices}

Herds enrolled in this study were milked in parlors $(\mathrm{n}=101)$, flat barns $(\mathrm{n}=11)$, and stallbarns $(\mathrm{n}=68)$. Herds milked in flat barns and stallbarns were combined for analysis because of similar herd sizes. The number of people participating in each milk quality team ranged from 2 to $11(\overline{\mathrm{X}}=5.4)$. Almost half of the teams $(48.4 \%)$ included an extension agent, a veterinarian, and a dairy field representative. Extension agents
$(65.5 \%)$ were team leaders 3 times more often than were veterinarians $(21.7 \%)$.

Herds having freestalls averaged more $(P<0.001)$ cows per herd than those in stallbarns (Table 1). When herds were categorized based on type of facility, average number of lactating cows per herd did not differ among BMSCC categories (Table 1).

A negative relationship was found between BMSCC and average milk production per cow per day $(\beta=$ $-0.011 ; P=0.001)$. The BMSCC was not affected by year or season.

Relationships between milk quality and facility type. Numerous differences in management were identified based on type of housing (Tables 2 and 3). No differences were detected in average DIM or percentage of cows in their first lactation based on type of facility (Table 2). Cows housed in freestalls produced more milk $(P<0.001)$ than those housed in stallbarns, and were milked with milking systems that had been updated more recently (Table 2). Milking efficiency was greater $(P<0.001)$ in freestall facilities, but the number of people milking per shift did not differ between facility types.

Table 2. Characteristics of Wisconsin dairy farms enrolled in milk quality program stratified by cow housing type.

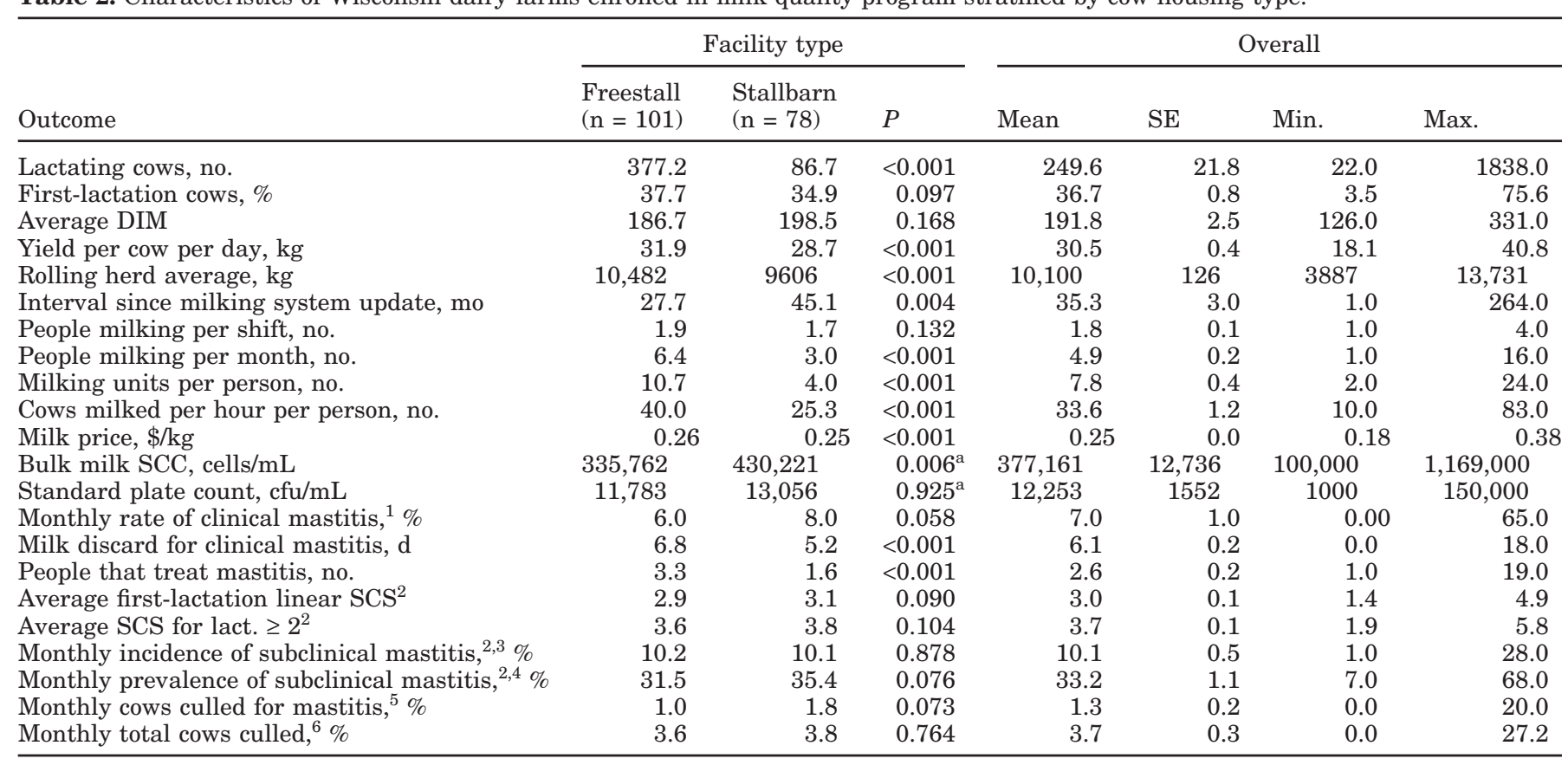

${ }^{\mathrm{a} A n a l y z e d}$ as $\log _{10}$.

${ }^{1}$ Reported monthly number of clinicals/number of actual cows $\times 100$.

${ }^{2}$ Calculated average for herds with DHI; $\mathrm{n}$ for overall $=142$; $\mathrm{n}$ for freestall facility $=81$; $\mathrm{n}$ for stallbarn facility $=61$.

${ }^{3}$ Percentage of cows with SCS $>4$ for first time in current lactation.

${ }^{4}$ Percentage of cows with SCS $>4$ at test.

${ }^{5}$ Percentage of cows culled due to mastitis reason in previous month.

${ }^{6}$ Percentage of total cows culled in previous month. 
Table 3. Management practices of Wisconsin dairy farms enrolled in milk quality program stratified by cow housing type.

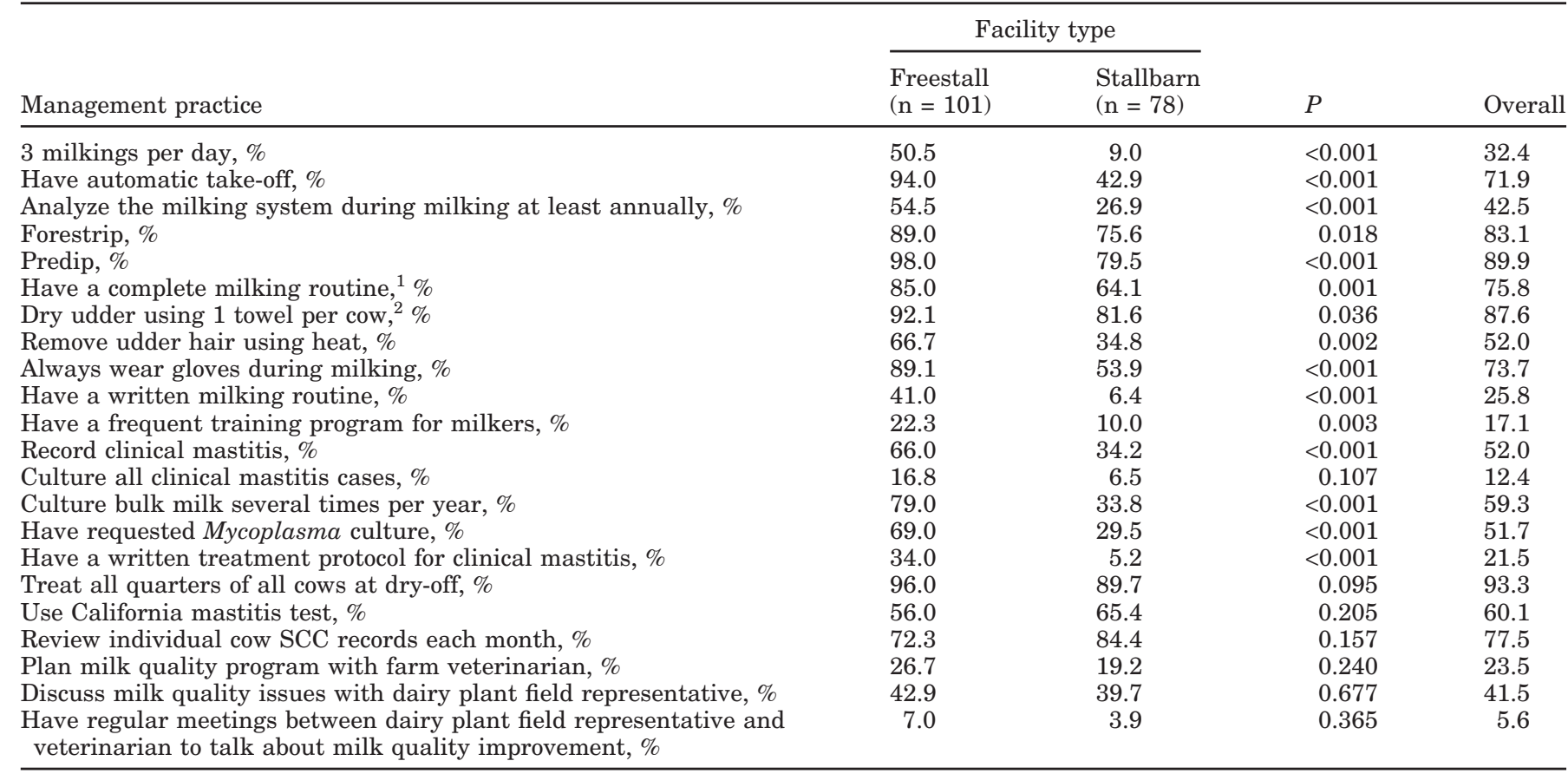

${ }^{1}$ Defined as use of a milking routine that includes forestrip, predip, dry, and postdip.

${ }^{2}$ Overall $(n=100)$; freestall facility $(n=54)$; stallbarn facility $(n=46)$.

The BMSCC was less $(P<0.001)$ and there was a tendency $(P=0.06)$ for reporting less clinical mastitis for herds housed in freestalls than for herds housed in stallbarns (Table 2). Milkers of stallbarn herds discarded milk for fewer $(P<0.001)$ days per clinical case of mastitis than did milkers in herds housed in freestalls. Farmers using freestall facilities received higher $(P<$ 0.001 ) milk prices than farmers using stallbarns (Table 2).

For herds enrolled in DHI, indices of individual cow SCC (first-lactation SCS, second and greater lactation SCS, and percentage of cows with SCS > 4) did not differ based on facility type (Table 2). Total number of cows culled per month was not different between herds using freestalls or stallbarns, but a tendency $(P=0.07)$ was detected for owners of herds housed in stallbarns to report mastitis as a culling reason more often than for owners of freestalls (Table 2).

Fewer $(P<0.001)$ herds housed in stallbarns were milked more than twice daily (Table 3 ). The number of milkings per day was not associated with BMSCC or the prevalence of subclinical mastitis. Freestall herds that milked cows 3 times daily reported reduced $(P<$ $0.05)$ estimated monthly rate of clinical mastitis $(4 \%)$ compared with freestall herds that milked twice daily (8\%). Overall, recommended milking practices such as forestripping, use of predip, and individual single-service towels to dry cows were highly adopted (Table 3).
Few farmers reported that they washed udders (rather than predipping) before milking $(8.4 \%)$ or handstripped after machine removal (4.5\%). In stallbarn herds, a tendency $(P=0.09)$ was detected for greater bacterial counts $(10,335 \mathrm{cfu} / \mathrm{mL})$ when cows were predipped than when predipping did not occur (3843 cfu/ $\mathrm{mL}$ ). Counts of Staph. aureus bacteria were greater $(773 \mathrm{cfu} / \mathrm{mL}$ ) in bulk tank milk of stallbarn herds that did not predip than in those that did predip (238 cfu/ $\mathrm{mL} ; P<0.05)$.

Adoption of milking management practices was markedly different based on facility (Table 3). Herds using freestalls were more $(P<0.001)$ likely to have milking systems analyzed during milking and to use a complete milking routine. Use of recommended premilking practices (forestripping and predipping) was less frequently adopted for operators of stallbarns (Table 3). Most herd managers reported the use of individual paper or cloth towel to dry udders, but some (7.3\%) reported the use of 1 towel to dry 2 cows. Operators of stallbarn herds wore gloves and removed udder hair less $(P<0.01)$ frequently than operators of freestall herds (Table 3 ).

Overall, usage of standardized protocols and training programs were limited and adoption of these practices was much less $(P<0.001)$ frequent for operators of stallbarns (Table 3). Training of milking personnel was 
Table 4. Financial characteristics of Wisconsin dairy farms enrolled in milk quality program stratified by cow housing type.

\begin{tabular}{|c|c|c|c|c|c|c|c|}
\hline \multirow[b]{3}{*}{ Financial characteristic } & \multicolumn{3}{|c|}{ Facility type } & \multirow{2}{*}{\multicolumn{4}{|c|}{ Overall }} \\
\hline & \multirow{2}{*}{$\begin{array}{l}\text { Freestall } \\
(\mathrm{n}=101)\end{array}$} & \multirow{2}{*}{$\begin{array}{l}\text { Stallbarn } \\
(\mathrm{n}=78)\end{array}$} & \multirow[b]{2}{*}{$P$} & & & & \\
\hline & & & & Mean & SE & Min. & Max. \\
\hline Standard milk production loss per cow ${ }^{1} \$$ & 3.60 & 4.54 & 0.013 & 3.96 & 0.18 & 0.00 & 11.96 \\
\hline Bulk milk SCC goal premium, $\$ / 45 \mathrm{~kg}$ & 0.54 & 0.52 & 0.478 & 0.53 & 0.02 & 0.00 & 1.30 \\
\hline Bulk milk SCC current premium, $\$ / 45 \mathrm{~kg}$ & 0.13 & 0.00 & 0.014 & 0.07 & 0.03 & -1.29 & 0.94 \\
\hline Drug cost per case, $\$$ & 20.40 & 16.88 & 0.091 & 18.77 & 1.02 & 1.50 & 68.00 \\
\hline Discard milk cost per case, $\$$ & 62.86 & 43.61 & $<0.001$ & 54.30 & 2.12 & 0.00 & 194.40 \\
\hline Vet/labor cost per case, $\$$ & 18.39 & 16.77 & 0.557 & 17.52 & 1.35 & 0.00 & 110.00 \\
\hline Monthly estimated loss from clinical mastitis per cow ${ }^{3} \$$ & 5.43 & 6.92 & 0.120 & 6.04 & 0.48 & 0.00 & 45.72 \\
\hline Standard loss from clinical mastitis per cow ${ }^{4} \$$ & 7.25 & 8.60 & 0.326 & 7.85 & 0.67 & 0.00 & 62.60 \\
\hline
\end{tabular}

infrequent. Overall frequency of training was reported as frequent (17.1\%), at hiring (43.3\%), or never (39.6\%).

Approximately one-half of the herds reported recording clinical cases of mastitis, but operators of freestall herds were 2 -fold more likely to record clinical mastitis than were operators of stallbarns (Table 3). Only a small percentage of herds reported culturing all cases of clinical mastitis. All clinical cases, selected clinical cases, and no clinical cases were cultured in $12.4,64.6$, and $23.3 \%$ of the herds, respectively. Operators of freestall herds were more $(P<0.05)$ likely to culture all clinical cases than were operators of stallbarn herds. Bulk milk cultures and Mycoplasma detection were performed more $(P<0.001)$ frequently in freestall herds (Table 3). Approximately one-fourth of the herds $(26.2 \%)$ had never submitted a bulk milk culture.

Although operators of both types of facilities reported high adoption of comprehensive dry-cow treatments, fewer $(P<0.001)$ operators of stallbarn herds were committed to use of a treatment protocol for clinical mastitis. Herds were equally aware of the importance of using the California mastitis test and reviewing individual cow SCC each month.

Milk quality was not a preferred topic of discussion among farmers and dairy professionals. Use of meetings among dairy professionals to discuss milk quality was rarely reported.

Operators of freestall herds received greater $(P<$ 0.05) premiums for BMSCC than operators of stallbarn herds, but operators of both facilities reported BMSCC goals of approximately 190,000 cells $/ \mathrm{mL}$ (Table 4). The total estimated monthly loss (standard production loss due to subclinical mastitis, foregone milk quality premi- ums, and standard loss attributed to clinical mastitis) was calculated to be $\$ 20.17$ per cow. Operators of stallbarn herds reported that they lost more $(P<0.05)$ production due to subclinical mastitis than did operators of freestalls, whereas milk-quality premium loss and losses from clinical mastitis did not differ between facility types (Table 4).

Indices used to calculate losses from clinical mastitis (drug cost, discarded milk cost, and veterinary/labor cost) exhibited a wide range of variation among farms. Estimated cost of a clinical case was $\$ 90.59$ with 20.8, 59.9 , and $19.3 \%$ of the loss related to drug cost, discarded milk cost, and veterinary/labor cost, respectively. Operators of freestall herds reported greater costs of discarded milk per clinical case of mastitis because of longer milk-discard times.

Relationships with milk quality by BMSCC category. Herds reporting low BMSCC contained more $(P<$ $0.01)$ lactating cows and were more $(P<0.05)$ productive than herds reporting high BMSCC (Table 5). Milking efficiency and the interval since the milking system was updated did not differ based on BMSCC.

The standard plate count increased and milk price decreased as BMSCC increased (Table 5). Estimated rate of clinical mastitis was almost 2-fold greater for herds reporting high BMSCC compared with herds having low and medium BMSCC. Number of milk discard days for each case of clinical mastitis did not differ among categories.

For herds with monthly individual cow SCC, incidence of subclinical mastitis was not different based on BMSCC, but prevalence of subclinical mastitis was less $(P<0.002)$ for herds having low BMSCC (Table 5). Prevalence of subclinical mastitis was about double for 
Table 5. Characteristics of Wisconsin dairy farms enrolled in milk quality program stratified by bulk milk SCC (BMSCC) category.

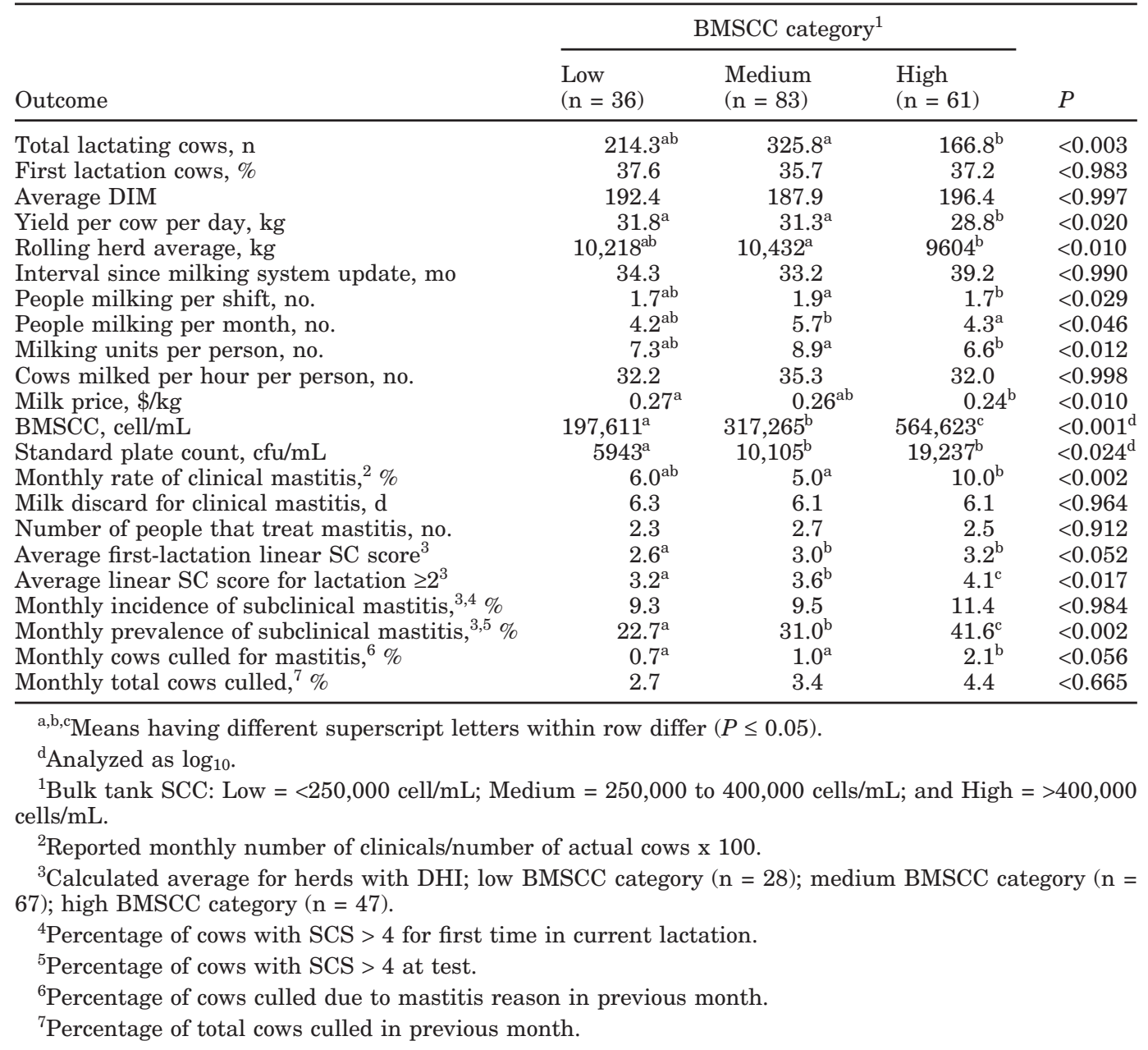

herds having high BMSCC, despite the tendency $(P=$ 0.06 ) to cull more cows for mastitis than herds having low BMSCC (Table 5).

Few milking practices were associated with BMSCC category (Table 6). Recommended milking practices such as forestripping, use of predip, and individual towels to dry cows were highly adopted by all herd managers. Operators of high BMSCC herds removed udder hair less $(P<0.01)$ frequently than did operators of low and medium BMSCC herds. Managers of herds having low and high BMSCC reported having a written milking routine less $(P<0.01)$ frequently than those having medium BMSCC. Fewer operators of herds having high BMSCC reported that they wore gloves during milking or had a written treatment protocol for clinical mastitis than operators of herds having low and medium BMSCC (Table 6).

Increased financial losses resulting from mastitis were apparent for high BMSCC herds (Table 7). Operators of herds with low BMSCC had more $(P<0.01)$ aggressive goals for BMSCC $(\overline{\mathrm{X}}=140,000$ cells $/ \mathrm{mL}$ vs. 187,630 and 217,705 for medium and high BMSCC herds, respectively), and received more $(P<0.001)$ milkquality premiums than operators of medium and high BMSCC herds (Table 7). Estimated total monthly loss per cow (standard production loss due to subclinical mastitis, lost milk-quality premiums, and standard loss from clinical mastitis) was $\$ 15.16, \$ 16.95$, and $\$ 27.51$ for low, medium, and high BMSCC herds, respectively.

Losses from clinical mastitis (drug, discarded milk, and veterinary/labor cost) did not differ among BMSCC categories (Table 7).

\section{Milking Performance}

The sequence of premilking cow preparation (forestripping and predipping) was not associated with most of the selected performance variables (Table 8). Use of forestripping before the application of predip was 
Table 6. Management practices of Wisconsin dairy farms enrolled in milk quality program stratified by bulk milk SCC (BMSCC) category.

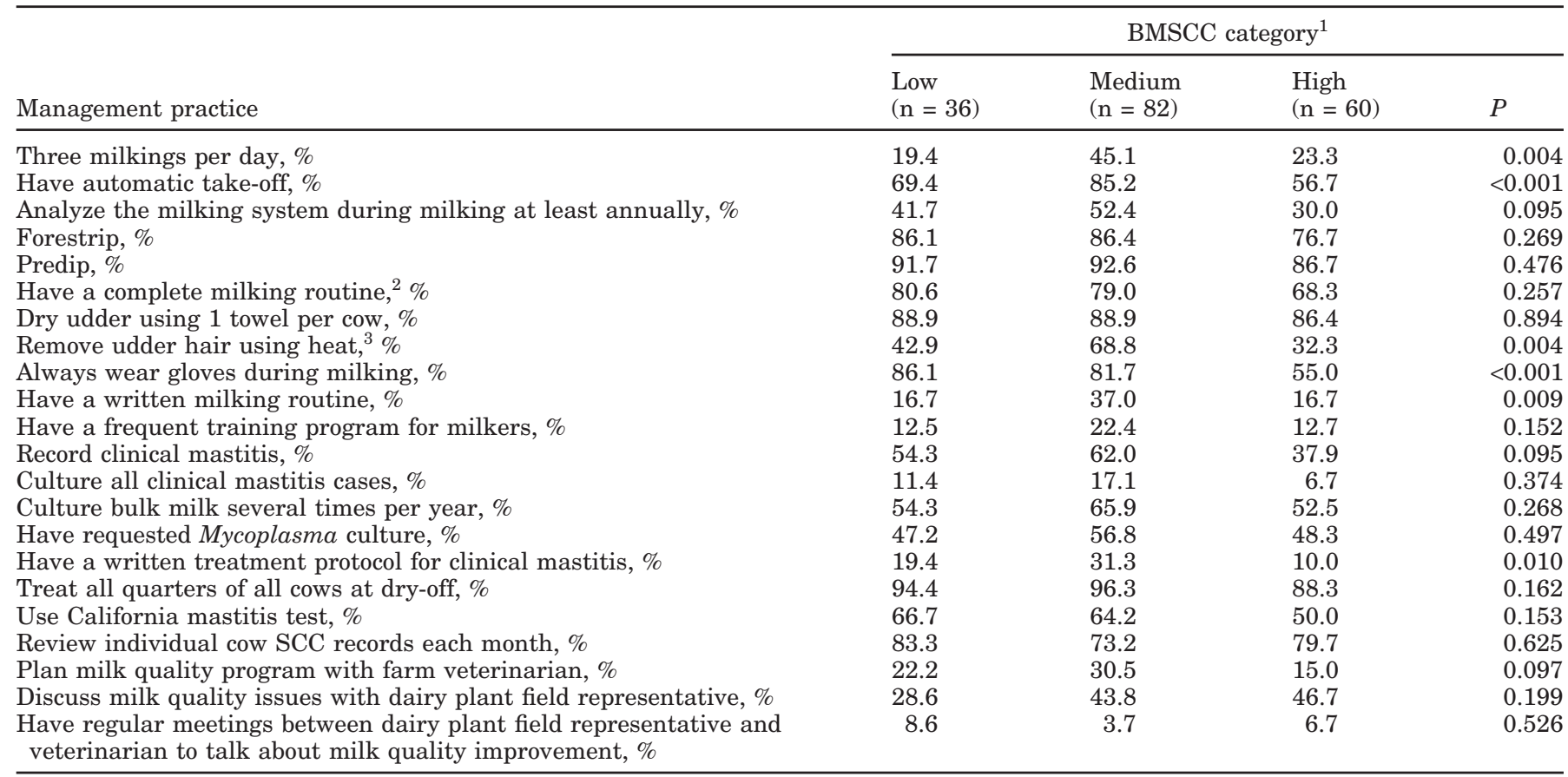

${ }^{1}$ Bulk tank SCC: Low $=<250,000$ cell $/ \mathrm{mL} ;$ Medium $=250,000$ to 400,000 cells $/ \mathrm{mL} ;$ and High $=>400,000$ cells $/ \mathrm{mL}$.

${ }^{2}$ Defined as use of a milking routine that includes forestrip, predip, dry and postdip.

${ }^{3}$ Low BMSCC category $(\mathrm{n}=21)$; medium BMSCC category $(\mathrm{n}=48)$; high BMSCC category $(\mathrm{n}=31)$.

Table 7. Financial characteristics of Wisconsin dairy farms enrolled in milk quality program stratified by bulk milk SCC (BMSCC) category.

\begin{tabular}{|c|c|c|c|c|}
\hline \multirow[b]{2}{*}{ Financial characteristic } & \multicolumn{4}{|c|}{ BMSCC category $^{1}$} \\
\hline & $\begin{array}{l}\text { Low } \\
(\mathrm{n}=36)\end{array}$ & $\begin{array}{l}\text { Medium } \\
(\mathrm{n}=83)\end{array}$ & $\begin{array}{l}\text { High } \\
(\mathrm{n}=61)\end{array}$ & $P$ \\
\hline \multicolumn{5}{|l|}{ Related to subclinical mastitis } \\
\hline Standard milk production loss per cow ${ }^{2} \$$ & $2.12^{\mathrm{a}}$ & $3.77^{\mathrm{b}}$ & $5.35^{\mathrm{c}}$ & $<0.001$ \\
\hline Bulk milk SCC goal premium, $\$ / 45 \mathrm{~kg}$ & $0.72^{\mathrm{a}}$ & $0.54^{\mathrm{b}}$ & $0.43^{\mathrm{c}}$ & $<0.002$ \\
\hline Bulk milk SCC current premium, $\$ / 45 \mathrm{~kg}$ & $0.47^{\mathrm{a}}$ & $0.14^{\mathrm{b}}$ & $-0.25^{\mathrm{c}}$ & $<0.001$ \\
\hline Milk quality premium loss per cow, ${ }^{3} \$$ & $4.69^{\mathrm{a}}$ & $7.33^{\mathrm{b}}$ & $11.79^{\mathrm{c}}$ & $<0.037$ \\
\hline \multicolumn{5}{|l|}{ Related to clinical mastitis } \\
\hline Drug cost per case, $\$$ & 21.26 & 17.74 & 18.91 & $<0.866$ \\
\hline Discard milk cost per case, $\$$ & 58.76 & 55.49 & 50.37 & $<0.843$ \\
\hline Vet/labor cost per case, $\$$ & 17.81 & 18.32 & 16.26 & $<0.990$ \\
\hline Monthly estimated loss from clinical mastitis per cow, ${ }^{4} \$$ & $7.25^{\mathrm{ab}}$ & $4.67^{\mathrm{a}}$ & $7.23^{\mathrm{b}}$ & $<0.040$ \\
\hline Standard loss from clinical mastitis per cow, ${ }^{5} \$$ & $8.35^{\mathrm{ab}}$ & $5.85^{\mathrm{a}}$ & $10.37^{\mathrm{b}}$ & $<0.008$ \\
\hline
\end{tabular}

${ }^{\mathrm{a}, \mathrm{b}, \mathrm{c}}$ Means with different superscripts within a row differ $(P \leq 0.05)$.

${ }^{1}$ Bulk tank SCC: Low $=<250,000$ cell $/ \mathrm{mL}$; Medium $=250,000$ to 400,000 cell $/ \mathrm{mL} ;$ and High $=>400,000$ cells/mL.

${ }^{2}$ Total average milk production loss due to cows with SCS greater than the goal standard multiplied by the milk price. Calculated with fixed milk price of $\$ 0.24 / \mathrm{kg}$.

${ }^{3}$ Difference between the current BMSCC premium and the goal BMSCC premium multiplied by the monthly total milk production.

${ }^{4}$ Sum of the total drug cost, discarded milk cost and vet/labor cost due to clinical mastitis per month.

${ }^{5}$ Calculated with fixed prices (drug cost $\$ 15.00$, milk price $\$ 0.24 / \mathrm{kg}$, and veterinary/labor cost $\$ 50.00$ ). 
Table 8. Influence of premilking cow preparation on milk quality performance for Wisconsin dairy farms enrolled in milk quality program stratified by cow housing type.

\begin{tabular}{|c|c|c|c|c|c|c|}
\hline \multirow[b]{3}{*}{ Outcome } & \multicolumn{6}{|c|}{ Facility type } \\
\hline & \multicolumn{3}{|c|}{ Freestall } & \multicolumn{3}{|c|}{ Stallbarn } \\
\hline & $\begin{array}{l}\text { Forestrip } \\
\text { then } \\
\text { predip } \\
(\mathrm{n}=35)\end{array}$ & $\begin{array}{l}\text { Predip } \\
\text { then } \\
\text { forestrip } \\
(\mathrm{n}=53)\end{array}$ & $P$ & $\begin{array}{l}\text { Forestrip } \\
\text { then } \\
\text { predip } \\
(\mathrm{n}=25)\end{array}$ & $\begin{array}{l}\text { Predip } \\
\text { then } \\
\text { forestrip } \\
(\mathrm{n}=25)\end{array}$ & $P$ \\
\hline Milk production/cow per $\mathrm{d}, \mathrm{kg}$ & 32.6 & 32.7 & 0.860 & 28.5 & 30.5 & 0.283 \\
\hline Cows milked per hour per operator, no. & 42.6 & 39.9 & 0.373 & 27.2 & 21.2 & 0.031 \\
\hline Monthly rate of clinical mastitis, ${ }^{1} \%$ & 5.7 & 5.4 & 0.829 & 8.6 & 8.9 & 0.733 \\
\hline Monthly incidence of subclinical mastitis, ${ }^{2} \%$ & 11.0 & 9.8 & 0.359 & 8.8 & 11.2 & 0.125 \\
\hline
\end{tabular}

${ }^{1}$ Percentage of reported monthly number of clinical cases/number of actual cows.

${ }^{2}$ Percentage of cows with SCS $>4$ for first time in current lactation (calculated average for DHI herds); freestall facility $(\mathrm{n}=81)$; stallbarn facility $(\mathrm{n}=61)$.

associated with faster $(P<0.05)$ milking performance for operators of stallbarn herds.

In herds using freestalls, frequent training of milking personnel resulted in faster $(P<0.01)$ milking speeds and lower $(P<0.05)$ estimated rates of clinical mastitis (Table 9). Use of a written milking routine and written treatment protocol was associated with faster $(P<$ 0.001 ) milking performances for operators of freestall facilities. Use of predip and a complete milking routine (forestripping, predipping, and drying before unit attachment) reduced $(P<0.05)$ estimates of clinical mastitis for freestall operations. In addition, in freestall herds, a tendency $(P=0.09)$ was detected for use of forestripping to result in faster milking performance and lower estimated rate of clinical mastitis.

For stallbarn herds, the majority of the selected milking practices were not associated with the selected performance variables (Table 9). Only the use of an individual towel per cow reduced $(P<0.05)$ estimated rates of clinical mastitis.

\section{Bulk Milk Culture}

The total bacterial count $(15,392 \mathrm{cfu} / \mathrm{mL})$ in submitted bulk milk samples $(\mathrm{n}=92)$ was close to the reported standard plate count obtained from the dairy plant

Table 9. Influence of milking routine on milk quality performance for Wisconsin dairy farms enrolled in milk quality program stratified by cow housing type.

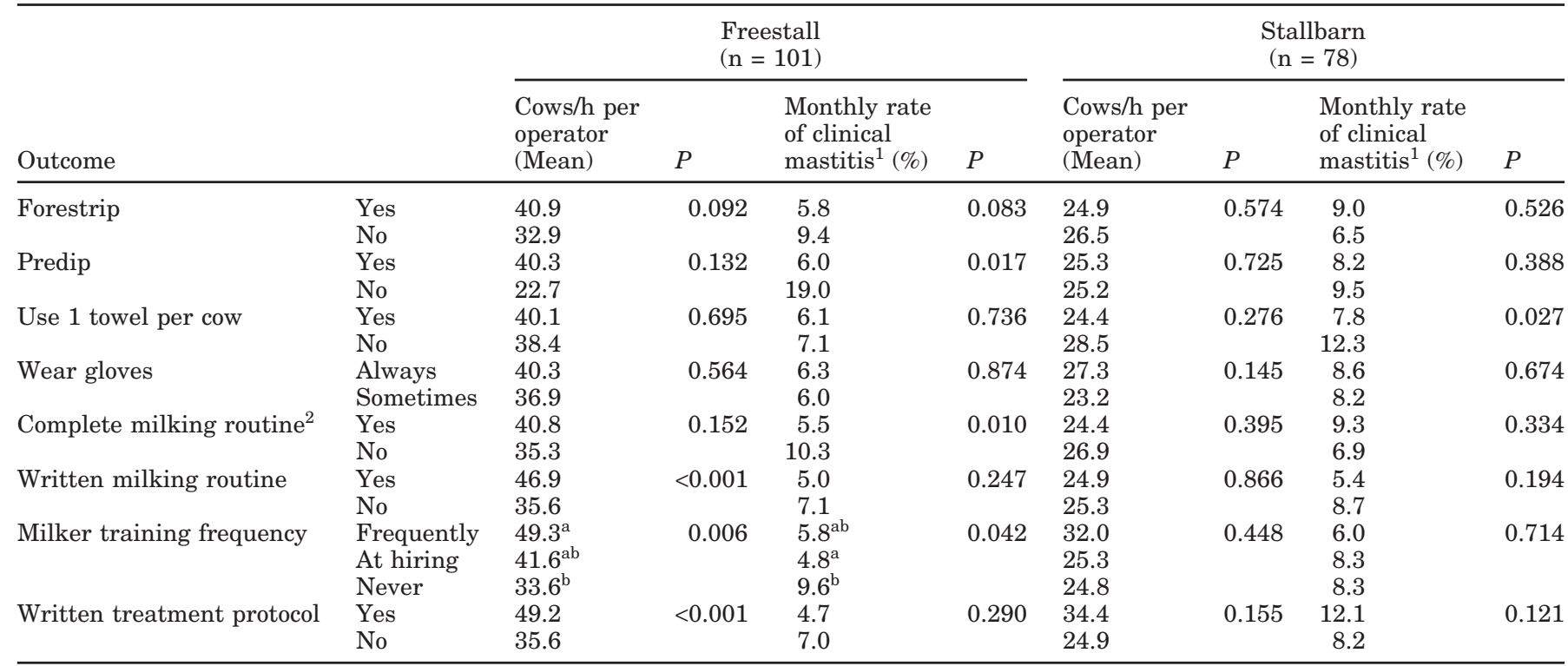

a,b Means having different superscript letters within column differ $(P \leq 0.05)$.

${ }^{1}$ Percentage of reported monthly number of clinical cases/number of actual cows.

${ }^{2}$ Defined as use of a milking routine that includes forestrip, predip, dry, and postdip. 
Table 10. Bulk milk culture of Wisconsin dairy farms enrolled in milk quality program stratified by cow housing type.

\begin{tabular}{|c|c|c|c|c|c|c|}
\hline Bacteria & \multicolumn{3}{|c|}{ Facility type } & & & \\
\hline Staphylococcus aureus, $\mathrm{cfu} / \mathrm{mL}$ & 0 & 0 & 0.181 & 0 & 0 & 63 \\
\hline Coagulase-negative staphylococci, cfu/mL & 278 & 500 & 0.342 & 100 & 310 & 1163 \\
\hline Streptococcus agalactiae, cfu/mL & 0 & 0 & 0.260 & 0 & 0 & 0 \\
\hline Others, ${ }^{4} \mathrm{cfu} / \mathrm{mL}$ & 80 & 215 & 0.485 & 18 & 133 & 763 \\
\hline Total count, cfu/mL & 5425 & 3900 & 0.500 & 1975 & 5160 & 10,063 \\
\hline Mycoplasma, presence & $\begin{array}{l}2 \text { herds } \\
(4.5 \%)\end{array}$ & $\begin{array}{l}3 \text { herds } \\
(6.4 \%)\end{array}$ & & $\begin{array}{r}5 \\
(5 .\end{array}$ & & \\
\hline
\end{tabular}

\footnotetext{
${ }^{1}$ Analyzed as $\log _{10}$.

${ }^{2}$ Streptococcus nonagalactiae and Enterococcus ssp.

${ }^{3}$ Enterobacteriaceae family.

${ }^{4}$ Bacillus ssp., Pseudomonas ssp., Pasteurella ssp., Corynebacterium ssp., Actinomycetes, yeast.
}

shipment reports $(12,253 \mathrm{cfu} / \mathrm{mL})$. A small prevalence of contagious pathogens was detected in the bulk milk (Table 10). Number of Staph. aureus in bulk-milk samples ranged from 0 to $4500 \mathrm{cfu} / \mathrm{mL}$, and $57.6 \%$ of the herds had counts equal to zero. Streptococcus agalactiae was isolated from bulk milk samples from 2 herds (both were housed in freestalls and had high BMSCC). Mycoplasma was isolated from bulk milk samples obtained from both freestall and stallbarn herds. Overall, fewer coliforms were isolated than other environmental pathogens (Table 10).

Facility type was not associated with types of pathogens recovered from bulk milk samples (Table 10). Total bacterial count was less $(P<0.05)$ for herds reporting low BMSCC (2325 cfu/mL) than for herds reporting medium $(5475 \mathrm{cfu} / \mathrm{mL})$ or high BMSCC $(5775 \mathrm{cfu} / \mathrm{mL})$. No other differences in bacterial counts differed among categories of BMSCC.

\section{DISCUSSION}

The population used in this observational study was composed of Wisconsin dairy herds enrolled in a statewide team-based milk quality improvement program. Herds enrolled in the program voluntarily. Enrolled herds reported greater BMSCC, milk yield per cow per day, and herd size than previously reported state averages (NASS-USDA, 2002).

Our data were collected by dairy professionals and producers, and authors did not have full control of the reporting process. Data were screened for unreliable values, but it is possible that some recording errors remained. As expected, herds using freestalls to house cattle were larger than herds using stallbarns. Many management practices and indices of milk quality were strongly associated with herd size and our analysis separated herds based on facility type to adjust for this confounding factor.

Managers of herds housed in freestalls reported better milk quality than herds housed in stallbarns. Herds housed in freestalls reported less BMSCC, greater milk yield, tended to have lower estimated incidence of clinical mastitis, and had less prevalence of subclinical mastitis. Many studies have reported the relationship between selected management practices and BMSCC (Fenlon et al., 1995; Wilson et al., 1997; Barkema et al., 1998a), but few have analyzed the influence of herd size on milk quality.

A study conducted in the Netherlands segregated dairy herds $(n=201)$ according to management style to assess differences in risk factors for mastitis (Barkema et al., 1999). Herds classified as "quick and dirty" were less likely to adopt conventional mastitis control practices and to maintain cow hygiene than herds characterized as "clean and accurate." In general, "quick and dirty" herds were larger and reported greater BMSCC. The study indicated that management style could confound the determination of risk factors for mastitis. Our study also reported differences between adoption of management practices and milk quality. We found, however, greater adoption of recommended management practices and reduced BMSCC in large herds (freestalls) than in small herds (stallbarns). Large herds were more likely to have regular maintenance of the milking machine, adopt a complete milking routine, use recommended premilking practices, and submit samples of bulk milk for microbiological analysis.

In our study, herds using freestalls adopted more standardized procedures (such as recording treatments, 
having written milking routines, and frequent training of milkers) than stallbarn herds. Managers of larger herds may receive more technical advice because they are often considered influential in their region. Some have proposed that dairy professionals should focus attention on large farms to decrease SCC in overall milk supplies (Fetrow et al., 2000; van Schaik et al., 2002). It is likely that larger farms enrolled in this study had access to more technical resources than smaller farms.

Herds that choose to control mastitis have significant financial advantages (Fetrow et al., 2000). In our study, freestall herds were more likely to adopt management practices related to mastitis control, and therefore, reported fewer financial losses related to mastitis. Operators of herds housed in freestalls also reported that they received greater BMSCC premiums. Most Wisconsin dairy farmers are offered milk-quality premiums based on BMSCC. Although the programs vary, in general, when the BMSCC is $\leq 350,000$ cells $/ \mathrm{mL}$, each decrease of 25,000 cells $/ \mathrm{mL}$ results in an additional premium of $\$ 0.10$ per $45 \mathrm{~kg}$ of milk. Farms having monthly average BMSCC more than 350,000 cell $/ \mathrm{mL}$ receive deductions per $45 \mathrm{~kg}$ of shipped milk. Use of SCC premiums is an effective incentive for the production of high quality milk. The Ontario SCC reduction program, based on penalties for elevated BMSCC, has had an important impact on BMSCC and antibiotic violations in Ontario (Sargeant et al., 1998). Researchers analyzed bulk milk data from dairy farms $(\mathrm{n}=9500)$ over a 10 -yr period. A decrease in the mean SCC of 80,000 cells $/ \mathrm{mL}$ was attributed to the penalty program, and a reduction of the regulatory limit to 500,000 cells $/ \mathrm{mL}$ caused a significant decrease in mean BMSCC. Dairy farms tend to respond positively to programs that encourage the production of high-quality milk resulting in better milk prices.

Operators of herds with greater BMSCC received less quality premiums, and consequently, received a reduced milk price. According to Fetrow et al. (2000), premium losses represent a significant economic loss for herds located in regions having a premium structure. Financial incentives associated with improvements in milk quality were larger for owners of herds having high BMSCC.

Cows were milked faster in freestall than in stallbarn herds. Use of more efficient milking facilities (parlors), more use of automatic take-offs, more frequent training of milking personnel, and more frequent use of written milking routines probably contributed to increased efficiency. Number of people milking per shift did not differ between facilities. Training seemed to be the fundamental factor that increased milking efficiency for operators of herds housed in freestalls. According to Fuhrmann (2002), training of milkers forces managers to define the milking process and can influence milking efficiency.

Faster milking performance did not increase estimates of clinical mastitis or BMSCC values. Dairy farm personnel work faster and maintain milk quality when they are well trained and receive adequate task descriptions. Use of a written milking routine was highly associated with milking performance. Fuhrmann (2002) stated that a written milking routine is the base that milking personnel require to ensure quality milk. In addition, well-defined tasks and recognition of the importance of the milking process are important to motivate milking personnel.

In freestall herds, the sequence of premilking cow preparation (forestripping or predip) did not influence herd performance. Order of forestripping and predipping seems to be a matter of opinion rather than a factor that influences milk quality. Both practices are highly recommended for mastitis control programs and were highly adopted in our study. The present study was unable to account for the quality of performance of the management practices reported by farmers. Associations were based on answers to questions regarding adoption of specific practices rather than how well practices were performed.

Herd managers in our study did not discuss milk quality issues frequently with dairy professionals. Herds reporting high BMSCC tended to report the lowest consultation rates with their herd veterinarians. Regular presence of dairy professionals on farms is reported to be an important factor to motivate farmers to adopt recommended management practices (Cavazos, 2003; Weinand and Conlin, 2003). Dairy professionals often influence adoption of technologies. A study that evaluated impacts of educational diagnostic teams reported greater changes of management performance for herds that worked with teams than herds that did not have a team (Weinand and Conlin, 2003). Team formation was useful to identify specific farm goals and resulted in decreased subclinical mastitis. Formation of self-selected dairy farm management teams may help to create the necessary commitment to achieve milk quality goals.

As shown by others (Fenlon et al., 1995; Wilson et al., 1997), BMSCC was positively associated with prevalence of subclinical mastitis. Herds reporting high BMSCC had an increased prevalence of cows with SCS greater than 4, but the incidence of subclinical mastitis did not differ among BMSCC categories. It is likely that differences in prevalence, but not incidence, can be explained by the presence of differing mastitic pathogens. In our study, contagious pathogens were more commonly found in high BMSCC herds and the recovery of Staph. aureus from bulk milk samples increased 
BMSCC. Other studies also reported a positive association between high BMSCC and prevalence of contagious pathogens in the herd (Fenlon et al., 1995; Barkema et al., 1998b). Contagious pathogens are characterized by chronic subclinical infections. Herds reporting having low BMSCC had fewer counts of contagious pathogens and less prevalence of subclinical mastitis. Incidence of subclinical infections was similar, but prevalence was not, probably because of differences in duration of infection of contagious vs. environmental pathogens.

Estimated rate of clinical mastitis was positively associated with BMSCC. Herds having high BMSCC estimated that they had more clinical cases compared with estimates for herds having low BMSCC. In addition, herds that reported high BMSCC had an increased prevalence of subclinical mastitis. Clinical mastitis and subclinical mastitis are associated. Clinical mastitis is the symptomatic form of udder infection and infection is the major factor altering milk SCC (Harmon, 1994). A consistently greater level of infection, caused by more prevalent subclinical mastitis, may lead to an increased probability of clinical mastitis.

Management practices that help to decrease the transmission of contagious pathogens (such as the use of gloves during milking and regular analysis of the milking system) were less often adopted by high BMSCC herds. In addition, operators of high BMSCC herds were less likely to maintain cow hygiene, to have a written treatment protocol for clinical mastitis, and tended to record fewer clinical cases. More exposure to bacteria and less control of clinical outcomes may increase risk for mastitis.

\section{CONCLUSIONS}

Our study found significant management differences based on facility type. Operators of herds housed in freestall and stallbarns reported differences in milk quality and adoption of management practices. Owners of freestall herds reported greater adoption of recommended practices of mastitis control that were associated with the production of milk of better quality. Association between the use of recommended management practices and the production of high-quality milk was probably associated with control of contagious pathogens.

Herds that produced high-quality milk received financial benefits. Increased quality premiums, decreased production losses, and reduction of clinical mastitis costs were associated with improvements in milk quality. Payment of quality premiums based on BMSCC seems to be a successful mechanism to encourage the production of high-quality milk.
Adoption of standardized protocols and frequent training of dairy operators resulted in greater milking performance and lower estimates of clinical mastitis. Protocols should describe tasks and define management procedures. Frequent training of personnel was an important practice used to achieve high quality milk.

\section{REFERENCES}

Barbano, D. 2004. The role of milk quality in addressing future dairy food marketing opportunities in a global economy. Pages 4751 in Proc. Natl. Mastitis Counc., Charlotte, NC. Natl. Mastitis Counc., Inc., Verona, WI.

Barkema, H. W., Y. H. Schukken, T. J. Lam, M. L. Beiboer, G. Benedictus, and A. Brand. 1998a. Management practices associated with low, medium, and high somatic cell counts in bulk milk. J. Dairy Sci. 81:1917-1927.

Barkema, H. W., Y. H. Schukken, T. J. Lam, M. L. Beiboer, H. Wilmink, G. Benedictus, and A. Brand. 1998b. Incidence of clinical mastitis in dairy herds grouped in three categories by bulk milk somatic cell counts. J. Dairy Sci. 81:411-419.

Barkema, H. W., J. D. Van der Ploeg, Y. H. Schukken, T. J. Lam, G. Benedictus, and A. Brand. 1999. Management style and its association with bulk milk somatic cell count and incidence rate of clinical mastitis. J. Dairy Sci. 82:1655-1663.

Cavazos, G. F. 2003. Useful ideas and principles for the implementation of reinforcement programs to keep milkers motivated. Pages 77-85 in Proc. Natl. Mastitis Counc., Fort Worth, TX. Natl. Mastitis Counc., Inc., Madison, WI.

Farnsworth, R. J. 1993. Microbiologic examination of bulk tank milk. Vet. Clin. North Am. Food Anim. Pract. 9:469-474.

Fenlon, D. R., D. N. Logue, J. Gunn, and J. Wilson. 1995. A study of mastitis bacteria and herd management practices to identify their relationship to high somatic cell counts in bulk tank milk. Br. Vet. J. 151:17-25.

Fetrow, J., S. Stewart, S. Eicker, R. Farnsworth, and R. Bey. 2000. Mastitis: An economic consideration. Pages 3-47 in Proc. Natl. Mastitis Counc., Atlanta, GA. Natl. Mastitis Counc., Inc., Madison, WI.

Fuhrmann, T. J. 2002. Quality milk starts with quality management. Pages 131-139 in Proc. Natl. Mastitis Counc., Orlando, FL, Natl. Mastitis Counc., Inc., Madison, WI.

Harmon, R. J. 1994. Physiology of mastitis and factors affecting somatic cell counts. J. Dairy Sci. 77:2103-2112.

NASS-USDA. 2002. Wisconsin Agricultural Statistics Service. Online. Available http://www.nass.usda.gov/wi/annbull/index.htm. Accessed April 17, 2004.

National Mastitis Council. 1999. Laboratory Handbook on Bovine Mastitis. Rev. ed. Natl. Mastitis Counc., Inc., Madison, WI.

Sargeant, J. M., Y. H. Schukken, and K. E. Leslie. 1998. Ontario bulk milk somatic cell count reduction program: Progress and outlook. J. Dairy Sci. 81:1545-1554.

SAS Institute, 2001. SAS/STAT, version 8.2 edition. SAS Inst., Inc., Cary, NC.

Schallibaum, M. 2001. Impact of SCC on the quality of fluid milk and cheese. Pages 38-46 in Proc. Natl. Mastitis Counc., Reno, NV. Natl. Mastitis Counc., Inc., Madison, WI.

van Schaik, G., M. Lotem, and Y. H. Schukken. 2002. Trends in somatic cell counts, bacterial counts, and antibiotic residue violations in New York State during 1999-2000. J. Dairy Sci. 85:782-789.

Weinand, D., and B. J. Conlin. 2003. Impacts of dairy diagnostic teams on herd performance. J. Dairy Sci. 86:1849-1857.

Wilson, D. J., H. H. Das, R. N. Gonzalez, and P. M. Sears. 1997. Association between management practices, dairy herd characteristics, and somatic cell count of bulk tank milk. JAVMA. 210:1499-1502. 